\title{
Pengaruh Rasio Keuangan Terhadap Pertumbuhan Laba Pada Perusahaan Sub Sektor Otomotif Dan Komponen Yang Terdaftar Di Bursa Efek Indonesia Periode 2014 - 2018
}

\author{
Mardiana \\ Fakultas Ekonomi Universitas 17 Agustus 1945 Samarinda \\ Camelia Verahastuti \\ Fakultas Ekonomi Universitas 17 Agustus 1945 Samarinda \\ Rosita Nur \\ Fakultas Ekonomi Universitas 17 Agustus 1945 Samarinda \\ rositanur161198@gmail.com
}

\begin{abstract}
Abstrak
Penelitian ini bertujuan untuk mengetahui dan menganalisis pengaruh Current Ratio (CR), Total Asset Turnover (TATO), dan Return On Asset (ROA) terhadap pertumbuhan laba pada perusahaan sub sektor otomotif dan komponen yang terdaftar di Bursa Efek Indonesia periode 2014 - 2018. Data yang digunakan dalam penelitian ini adalah data sekunder yang bersumber dari data ringkasan kinerja perusahaan tercatat tahunan, yang diperoleh dari website resmi www.idx.co.id. Hasil penelitian secara parsial menunjukan bahwa variabel Current Ratio (CR) berpengaruh negatif tidak signifikan terhadap pertumbuhan laba; variabel Total Asset Turnover (TATO) berpengaruh negatif tidak signifikan terhadap pertumbuhan laba; sedangkan variabel Return On Asset (ROA) berpengaruh positif signifikan terhadap pertumbuhan laba . Secara simultan menunjukan bahwa variabel Current Ratio (CR), Total Asset Turnover (TATO) ,dan Return On Asset (ROA) berpengaruh signifikan terhadap pertumbuhan laba.
\end{abstract}

Kata Kunci : Pertumbuhan Laba, Current Ratio (CR), Total Asset Turnover (TATO),dan Return On Asset (ROA).

\section{The Influence of Financial Ratios on Profit Growth in Automotive Sub- Sector Companies and Components Listed on the Indonesia Stock Exchange for the Period 2014 - 2018}

\begin{abstract}
This study aims to determine and analyze the effect of Current Ratio (CR), Total Asset Turnover (TATO), and Return On Asset (ROA) on profit growth in automotive sub-sector companies and components listed on the Indonesia Stock Exchange for the period 2014-2018. used in this study is secondary data sourced from annual performance summary data of listed companies, obtained from thewebsite official www.idx.co.id.. The results of the study partially show that thevariable Current Ratio (CR)has a negative and insignificant effect on profit growth;variable Total Asset Turnover (TATO)has a negative and insignificant effect on profit growth; while the variable Return on Assets (ROA) has a significant positive effect on profit growth. Simultaneously, it shows that the variables Current Ratio (CR), Total Asset Turnover (TATO), and Return On Asset (ROA) have a significant effect on profit growth.
\end{abstract}

Keywords: Profit Growth, Current Ratio (CR), Total Asset Turnover (TATO), and Return On Asset (ROA). 


\section{PENDAHULUAN}

Indonesia adalah salah satu negara dengan industri otomotif yang aktif. Hal ini terlihat dari banyaknya produk-produk otomotif yang digunakan baik dari jenis maupun jumlahnya. Terdapat 13 perusahaan sub sektor otomotif dan komponen yang terdaftar di Bursa Efek Indonesia.

Sub sektor otomotif dan komponen ini memiliki mata rantai yang lengkap mulai dari pembuatan komponen, produksi dan perakitan kendaraan, jaringan distribusi dan penjualan, hingga pelayanan penjualan. Perkembangan tersebut akan menciptakan sebuah industri otomotif yang mandiri, kemandirian otomotif memberikan peluang bagi perusahaan otomotif indonesia untuk melakukan ekspor produk otomotif yang berkualitas dan berdaya saing tinggi ke luar negeri.

Pemerintah melalui Kementerian Perindustrian, mendorong para pelaku usaha untuk memproduksi produk dengan kualitas terbaik agar produk industri otomotif indonesia mampu dan layak bersaing dipasar Internasional. Kementerian Perindustrian mencatat, kinerja industri otomotif di Indonesia semakin melesat, terlihat dari jumlah ekspor dalam bentuk komponen kendaraan merangkak naik hingga 13 kali lipat, dari 6,2 juta unit pada 2016 menjadi 81 juta unit di 2017. Keadaan seperti ini tentunya menciptakan peluang investasi pada sektor otomotif. Investor akan memilih perusahaan yang menguntungkan sebagai sarana investasi. Sebelum melakukan investasi diperlukan analisis untuk melihat kinerja suatu perusahaan, dengan demikian tidak akan terjadi kesalahan investasi.

Kinerja keuangan perusahaan merupakan hal utama yang dilihat oleh investor sebagai alasan investasi. Kinerja keuangan perusahaan salah satunya dapat dilihat dari pertumbuhan laba perusahaan, tingginya pertumbuhan laba menginterpretasikan kinerja keuangan perusahaan yang baik.

Pertumbuhan laba sendiri merupakan salah satu kunci yang menunjukkan keberhasilan suatu perusahaan, untuk melihat tingkat pertumbuhan laba perusahaan tersebut maka dibutuhkan laporan keuangan perusahaan untuk dianalisis, sehingga seberapa besar tingkat pertumbuhannya, mengalami peningkatan atau penurunan akan terlihat dalam laporan keuangan perusahaan.

\section{TINJAUAN PUSTAKA}

\section{Manajemen Keuangan}

Pengertian manajemen keuangan menurut Fahmi (2011:12) "Manajemen keuangan adalah suatu kegiatan perencanaan, penganggaran, pemeriksaan, pengelolaan, pengendalian, pencarian dan penyimpanan dana yang dimiliki oleh organisasi atau perusahaan.”.

\section{Pertumbuhan laba}

Menurut Nurhadi (2011:141) : "Pertumbuhan laba menunjukan presentase kenaikan laba yang akan dihasilkan perusahaan dalam bentuk laba bersih".

\section{Current ratio (CR)}

Menurut Kasmir (2014:134) : "Rasio lancar merupakan rasio untuk mengukur kemampuan perusahaan dalam membayar kewajiban jangka pendek atau utang yang segera jatuh tempo pada saat ditaguh secara keseluruhan".

\section{Total asset turnover (TATO)}

Menurut Brigham dan Houston (2010:139): “ Rasio yang mengukur perputaran seluruh asset perusahaan, dan dihitung dengan membagi penjualan dengan total asset".

\section{Return on asset (ROA)}

Menurut Mardiyanto (2009:196) : "Rasio digunakan untuk mengukur kemampuan perusahaan dalam menghasilkan laba yang berasal dari aktivitas investasi”.

\section{METODE PENELITIAN}

\section{Teknik Pengumpulan Data}

Penelitian ini menggunakan penelitian Kepustakaan (library research) yaitu data yang dikumpulkan dalam penelitian ini adalah data sekunder berupa laporan keuangan Perusahan sub sektor otomotif dan komponen yang terdaftar di Bursa Efek Indonesia periode 2014-2018 yang dipublikasikan di website www.idx.co.id 


\title{
Populasi dan Sampel
}

Populasi dalam penelitian ini adalah seluruh perusahaan sub sektor otomotif dan komponen yang terdaftar di Bursa Efek Indonesia periode 2014-2018. sehingga diperoleh jumlah populasi sebanyak 13 perusahaan. Penelitian ini menggunakan purposive sampling sebagai metode pengambilan data. Purposive sampling adalah teknik yang digunakan peneliti jika memiliki pertimbangan-pertimbangan tertentu dalam pengambilan sampelnya. Adapun pertimbangan atau kriteria yang digunakan dalam pengambilan sampel ini adalah :

1. Perusahaan yang terdaftar di Bursa Efek Indonesia periode 2014-2018.

2. Perusahan yang bergerak dalam sub sektor Otomotif dan Komponen periode 2014-2018.

3. Perusahaan yang memiliki laporan keuangan selama periode 2014-2018

Berdasarkan pertimbangan atau kriteria diatas, maka dari 13 perusahaan ada 10 perusahaan yang dijadikan sampel pada penelitian ini.

\author{
Alat Analisis \\ Alat analisis yang akan digunakan dalam penelitian ini adalah sebagai berikut : \\ Analisis Regresi Linear Berganda \\ Rumus analisis regresi linear berganda adalah : \\ $\mathrm{Y}=\mathrm{a}+\mathrm{b}_{1} \mathrm{X}_{1}+\mathrm{b}_{2} \mathrm{X}_{2}+\mathrm{b}_{3} \mathrm{X}_{3}+\mathrm{e}$ \\ Keterangan : \\ Y : Pertumbuhan Laba \\ a : Konstanta \\ $\mathrm{b}_{1} \mathrm{~b}_{2} \mathrm{~b}_{3} \quad$ : Koefisiensi regresi masing-masing variabel independen \\ $\mathrm{X}_{1} \quad$ : Current Ratio (CR) \\ $\mathrm{X}_{2} \quad:$ Total Asset Turnover (TATO) \\ $\mathrm{X}_{3} \quad:$ Return On Asset (ROA) \\ e : Error
}

\section{Pertumbuhan Laba.}

Pertumbuhan laba dapat dipakai sebagai alat penilaian bagaimana kinerja perusahaan. Menurut Nurhadi (2011:141) : “Pertumbuhan laba menunjukan presentase kenaikan laba yang akan dihasilkan perusahaan dalam bentuk laba bersih". Menurut Harahap (2009:310) : "Pertumbuhan laba dihitung dengan cara mengurangkan laba periode sekarang dengan laba periode sebelumnya, kemudian dibagi dengan laba pada periode sebelumya".

Pertumbuhan laba $=\underline{\text { Laba Bersih Tahunt }- \text { Laba Bersih Tahunt }-1} \times 100 \%$

Laba Bersih Tahun $\mathrm{t}-1$

Keterangan:

Laba Bersih Tahunt : Laba bersih tahun berjalan

Laba Bersih Tahunt -1 : Laba bersih tahun sebelumnya.

\section{Current Ratio (CR)}

Menurut Kasmir (2014:134) : "Rasio lancar merupakan rasio untuk mengukur kemampuan perusahaan dalam membayar kewajiban jangka pendek atau utang yang segera jatuh tempo pada saat ditagih secara keseluruhan".

$$
\text { Current Ratio }(\mathrm{CR})=\frac{\text { Current Asset }}{\text { Current Liabilities }}
$$

Total Asset Turnover (TATO)

Menurut Brigham dan Houston (2010:139) :“ Rasio yang mengukur perputaran seluruh asset perusahaan, dan dihitung dengan membagi penjualan dengan total asset”. 
Total Asset Turnover $($ TATO $)=\frac{\text { Penjualan Bersih }}{\text { Total Aktiva }}$

\section{Return On Assets (ROA)}

Menurut Mardiyanto (2009:196) adalah "Rasio digunakan untuk mengukur kemampuan perusahaan dalam menghasilkan laba yang berasal dari aktivitas investasi”. Rasio ini menunjukan berapa besar laba bersih diperoleh perusahaan bila di ukur dari nilai aktiva.

Return On Assets $(\mathrm{ROA})=\underline{\text { Laba bersih setelah pajak }} \times 100 \%$

\section{Total Aktiva}

\section{Pengujian Hipotesis}

\section{Uji Pengaruh Individual/Parsial (Uji t)}

Pengujian ini menggunakan tingkat signifikansi sebesar 5\% atau 0,05. Kriteria pengambilan keputusan uji t adalah :

- Jika nilai sig <0,05 atau Thitung > Ttabel maka hipotesis diterima.

- Jika nilai sig > 0,05 atau Thitung < Ttabel maka hipotesis ditolak.

\section{Uji Pengaruh Simultan (Uji F)}

Pengujian ini menggunakan tingkat signifikansi sebesar $5 \%$ atau 0,05 . Kriteria pengambilan keputusan uji $\mathrm{F}$ adalah :

- Jika nilai sig <0,05 atau Fhitung > Ftabel maka hipotesis diterima.

- Jika nilai sig > 0,05 atau Fhitung < Ftabel maka hipotesis ditolak.

\section{HASIL DAN PEMBAHASAN \\ Pengujian Hipotesis \\ Regresi Linier Berganda}

Tabel 1 : Hasil Analisis Regresi Linier Berganda

\begin{tabular}{|c|c|c|c|c|c|c|}
\hline \multicolumn{7}{|c|}{ Coefficients $^{\mathrm{a}}$} \\
\hline \multirow[b]{2}{*}{ Model } & & \multicolumn{2}{|c|}{$\begin{array}{l}\text { Unstandardized } \\
\text { Coefficients }\end{array}$} & \multirow{2}{*}{\begin{tabular}{|l} 
Standardized \\
Coefficients
\end{tabular}} & \multirow[b]{2}{*}{$t$} & \multirow[b]{2}{*}{ Sig. } \\
\hline & & $\mathrm{B}$ & Std. Error & & & \\
\hline \multirow[t]{4}{*}{1} & (Constant) & 3.321 & .076 & & 43.420 & .000 \\
\hline & CR & -.016 & .013 & -.183 & -1.183 & .245 \\
\hline & TATO & -.019 & .012 & -.231 & -1.617 & .115 \\
\hline & ROA & .094 & .043 & .348 & 2.196 & .035 \\
\hline
\end{tabular}

Hasil pengujian persamaan regresi pada tabel diatas dapat dijelaskan sebagai berikut :

Pertumbuhan Laba $(Y)=3,321 \alpha-0,016 X_{1}-0,019 X_{2}+0,094 X_{3}+e$

Berdasarkan model regresi pada tabel diatas dapat disimpulkan bahwa :

a. Konstanta $(\alpha)$ : Nilai Konstanta sebesar 3.321 dengan arah hubungannya positif menunjukan bahwa apabila variabel independen dianggap konstan maka pertumbuhan laba telah mengalami peningkatan sebesar 3,321 atau 332,1\%

b. Koefisien $\left(\mathrm{b}_{1}\right)$ : Nilai Koefisien Current Ratio (CR) sebesar -0,016 dengan arah hubungan negatif menunjukan bahwa setiap kenaikan current ratio maka akan diikuti oleh penurunan pertumbuhan laba sebesar 0,016 atau 1,6\% dengan asumsi variabel lain dianggap konstan. 
c. Koefisien $\left(\mathrm{b}_{2}\right)$ : Nilai Koefisien Total Asset Turnover (TATO) sebesar -0,019 dengan arah hubungan negatif menunjukan bahwa setiap kenaikan total asset trunover maka akan diikuti oleh penurunan pertumbuhan laba sebesar 0,019 atau 1,9\% dengan asumsi variabel lain dianggap konstan.

d. Koefisien $\left(\mathrm{b}_{3}\right)$ : Nilai Koefisien Return On Asset (ROA) sebesar 0,094 dengan arah hubungan positif menunjukan bahwa setiap kenaikan return on asset maka akan diikuti oleh kenaikan pertumbuhan laba sebesar 0,094 atau 9,4\% dengan asumsi variabel lain dianggap konstan.

\section{Uji Pengaruh Individual/Parsial (Uji t)}

Tabel 2: Hasil Uji Parsial (Uji t)

\begin{tabular}{|c|c|c|c|c|c|c|}
\hline \multicolumn{7}{|c|}{ Coefficients $^{\mathrm{a}}$} \\
\hline \multirow{2}{*}{\multicolumn{2}{|c|}{ Model }} & \multicolumn{2}{|c|}{ Unstandardized Coefficients } & \multirow{2}{*}{\begin{tabular}{|r} 
Standardized \\
Coefficients
\end{tabular}} & \multirow[b]{2}{*}{$\mathrm{t}$} & \multirow[b]{2}{*}{ Sig. } \\
\hline & & B & Std. Error & & & \\
\hline \multirow[t]{4}{*}{1} & (Constant) & 3.321 & .076 & & 43.420 & .000 \\
\hline & $\mathrm{CR}$ & -.016 & .013 & -.183 & -1.183 & .245 \\
\hline & TATO & -.019 & .012 & -.231 & -1.617 & .115 \\
\hline & ROA & .094 & .043 & .348 & 2.196 & .035 \\
\hline
\end{tabular}

Hasil pengujian rasio likuiditas yang diukur dengan current ratio, rasio aktivitas yang diukur dengan total asset trunover dan rasio profitabilitas yang diukur dengan return on asset terhadap pertumbuhan laba adalah :

$\mathbf{H}_{1}$ : Nilai uji t variabel Current Ratio $(\mathrm{CR}) \mathrm{X}_{1}$ berpengaruh sebesar -0,016 atau -1,6\%. Nilai thitung sebesar $1,183<2,01290$ ttabel dengan tingkat signifikan $0,245>0,05$, sehingga rasio likuiditas yang diukur dengan current ratio berpengaruh negatif tidak signifikan terhadap pertumbuhan laba pada perusahaan sub sektor otomotif dan komponen yang terdaftar di Bursa Efek Indonesia periode 2014-2018, sehingga hipotesis pertama di tolak.

$\mathbf{H}_{2}$ : Nilai uji t variabel Total Asset Turnover (TATO) $\mathrm{X}_{2}$ berpengaruh sebesar -0,019 atau 1,9\%. Nilai thitung sebesar $-1,617<2,01290$ ttabel dengan tingkat signifikan $0,115>0,05$, sehingga rasio aktivitas yang diukur dengan total asset turnover berpengaruh negatif tidak signifikan terhadap pertumbuhan laba pada perusahaan sub sektor otomotif dan komponen yang terdaftar di Bursa Efek Indonesia periode 20142018, sehingga hipotesis kedua di tolak.

$\mathbf{H}_{3}$ : Nilai uji t variabel Return On Asset (ROA) $\mathrm{X}_{3}$ berpengaruh sebesar 0,094 atau 9,4\%. Nilai thitung sebesar $2.196>$ ttabel 2,01290 dengan tingkat signifikan 0,035<0,05, sehingga profitabilitas yang diukur dengan return on asset berpengaruh positif signifikan terhadap pertumbuhan laba pada perusahaan sub sektor otomotif dan komponen yang terdaftar di Bursa Efek Indonesia periode 2014-2018, sehingga hipotesis ketiga di terima.

\section{a. Uji Pengaruh Simultan (Uji F)}

Tabel 3 : Hasil Uji Simultan (Uji F)

\begin{tabular}{|l|l|l|l|l|l|l|}
\hline \multicolumn{9}{|c|}{ ANOVA $^{\text {a }}$} \\
\hline Model & Sum of Squares & df & Mean Square & F & Sig. \\
\hline \multirow{5}{*}{1} & Regression & .004 & 3 & .001 & 5.688 & $.003^{\text {b }}$ \\
\cline { 2 - 7 } & Residual & .008 & 36 & .000 & & \\
\cline { 2 - 6 } & Total & .012 & 39 & & & \\
\hline a. Dependent Variable: Pertumbuhan Laba \\
b. Predictors: (Constant), ROA, TATO, CR \\
\hline
\end{tabular}


Hasil pengujian diatas maka diperoleh sebagai berikut :

$\mathbf{H}_{4}$ : Secara simultan nilai Fhitung $5.688>$ Ftabel 2,80 dengan nilai signifikan 0,003 < 0,05. Menunjukan bahwa Current Ratio (CR), Total Asset Turnover (TATO), dan Return On Asset (ROA) secara bersamasama (Simultan) berpengaruh signifikan terhadap pertumbuhan laba pada perusahaan sub sektor otomotif dan komponen yang terdaftar di Bursa Efek Indonesia periode 2014-2018, sehingga hipotesis keempat di terima.

\section{b. Uji Koefisien Determinasi $\left(\mathbf{R}^{2}\right)$.}

Tabel 4 : Hasil Uji Koefisien Determinasi $\left(\mathrm{R}^{2}\right)$

\begin{tabular}{|l|l|l|l|l|}
\hline \multicolumn{4}{|l|}{ Model Summary } \\
\hline Model & $\mathrm{R}$ & $\mathrm{R}$ Square & $\begin{array}{l}\text { Adjusted R } \\
\text { Square }\end{array}$ & $\begin{array}{l}\text { Std. Error of the } \\
\text { Estimate }\end{array}$ \\
\hline 1 & $.567^{\mathrm{a}}$ & .322 & .265 & .01501 \\
\hline a. Predictors: (Constant), ROA, TATO, CR \\
\hline
\end{tabular}

Hasil pengujian diatas diketahui Adjusted $R$ Square sebesar 0,265 x 100 didapat 26,5 hal ini berarti variabel yang digunakan dalam penelitian ini berpengaruh sebanyak 26,5\% terhadap pertumbuhan laba pada perusahaan sub sektor otomotif dan komponen yang terdaftar di Bursa Efek Indonesia periode 2014-2018. Sedangkan sisanya sebanyak 73,5\% dipengaruhi oleh variabel lain yang tidak digunakan dalam penelitian ini. Pembahasan

\section{Pengaruh Current Ratio (CR) Terhadap Pertumbuhan Laba.}

Hasil penelitian yang diperoleh mengenai pengaruh Current Ratio (CR) terhadap pertumbuhan laba pada perusahaan sub sektor otomotif dan komponen yang terdaftar di Bursa Efek Indonesia periode 20142018, menunjukkan nilai coefficient sebesar -0,016 dengan nilai signifikansi sebesar 0,245, dimana nilai ini lebih besar dari tingkat signifikan 0,05, serta nilai thitung sebesar -1,183 dimana nilai ini lebih kecil dari ttabel sebesar 2,01290, dapat disimpulkan bahwa variabel Current Ratio (CR) berpengaruh negatif tidak signifikan terhadap pertumbuhan laba pada perusahaan sub sektor otomotif dan komponen yang terdaftar di Bursa Efek Indonesia periode 2014-2018.

Current Ratio (CR) digunakan untuk mengukur kemampuan perusahaan dalam membayar kewajiban jangka pendeknya dengan menggunakan aktiva lancar yang dimiliki. Tidak ada ketentuan yang mutlak tentang berapa tingkat Current Ratio (CR) yang dianggap baik atau harus dipertahankan oleh perusahaan. Nilai Current Ratio (CR) yang tinggi tidak menjamin adanya peningkatan pertumbuhan laba perusahaan. Hal ini dapat terjadi karena kemampuan perusahaan dalam memenuhi kewajiban jangka pendeknya tidak memberikan jaminan ketersediaan modal kerja guna mendukung aktivitas operasional perusahaan yang bertujuan untuk meningkatkan pertumbuhan laba perusahaan.

\section{Pengaruh Total Asset Turnover (TATO) Terhadap Pertumbuhan Laba.}

Hasil penelitian yang diperoleh mengenai pengaruh Total Asset Turnover (TATO) terhadap pertumbuhan laba pada perusahaan sub sektor otomotif dan komponen yang terdaftar di Bursa Efek Indonesia periode 2014-2018, menunjukkan nilai coefficient sebesar -0,019 dengan nilai signifikansi sebesar 0,115 dimana nilai ini lebih besar dari tingkat signifikan 0,05, serta nilai thitung sebesar -1,617 dimana nilai ini lebih kecil dari ttabel sebesar 2,01290, dapat disimpulkan bahwa variabel Total Asset Turnover (TATO) berpengaruh negatif tidak signifikan terhadap pertumbuhan laba pada perusahaan sub sektor otomotif dan komponen yang terdaftar di Bursa Efek Indonesia periode 2014-2018.

Nilai Total Asset Turnover (TATO) yang tinggi tidak menjamin adanya peningkatan pertumbuhan laba perusahaan, hal ini dapat terjadi ketika perusahaan melakukan penurunan harga produknya untuk menghindari depresiasi, dengan demikian nilai Total Asset Turnover (TATO) akan meningkat namun tidak terjadi peningkatan pertumbuhan laba perusahaan. 


\section{Pengaruh Return On Asset (ROA) Terhadap Pertumbuhan Laba.}

Hasil penelitian yang diperoleh mengenai pengaruh Return On Asset (ROA) terhadap pertumbuhan laba pada perusahaan sub sektor otomotif dan komponen yang terdaftar di Bursa Efek Indonesia periode 2014-2018, menunjukkan nilai coefficient sebesar 0,094 dengan nilai signifikansi sebesar 0,035 dimana nilai ini lebih kecil dari tingkat signifikan 0,05, serta nilai thitung sebesar 2.196 dimana nilai ini lebih besar dari ttabel sebesar 2,01290, dapat disimpulkan bahwa variabel Return On Asset (ROA) berpengaruh positif signifikan terhadap pertumbuhan laba pada perusahaan sub sektor otomotif dan komponen yang terdaftar di Bursa Efek Indonesia periode 2014-2018.

Return On Asset (ROA) menunjukkan berapa besar laba bersih yang diperoleh perusahaan bila diukur dari nilai aktiva. Peningkatan Return On Asset (ROA) akan meningkatkan aktivitas pertumbuhan laba. Return On Asset (ROA) yang tinggi menunjukkan bahwa perusahaan berusaha meningkatkan penjualan atau pendapatan sehingga pertumbuhan laba juga ikut meningkat.

\section{Pengaruh Current Ratio (CR),Total Asset Turnover (TATO), dan Return On Asset (ROA) Terhadap Pertumbuhan Laba.}

Hasil penelitian yang diperoleh mengenai pengaruh Current Ratio (CR), Total Asset Turnover (TATO), dan Return On Asset (ROA) terhadap pertumbuhan laba pada perusahaan sub sektor otomotif dan komponen yang terdaftar di Bursa Efek Indonesia periode 2014-2018, menunjukkan nilai signifikansi sebesar 0,003 dimana nilai ini lebih kecil dari tingkat signifikan 0,05 serta nilai Fhitung sebesar 5.688 dimana nilai ini lebih besar dari Ftabel sebesar 2,80, dapat disimpulkan bahwa variabel Current Ratio (CR), Total Asset Turnover (TATO), dan Return On Asset (ROA) secara bersama-sama (Simultan) berpengaruh signifikan terhadap pertumbuhan laba pada perusahaan sub sektor otomotif dan komponen yang terdaftar di Bursa Efek Indonesia periode 2014-2018, dapat diartikan bahwa peningkatan Current Ratio (CR), Total Asset Turnover (TATO), dan Return On Asset (ROA) secara bersama-sama (Simultan) mampu meningkatkan pertumbuhan laba pada perusahaan sub sektor otomotif dan komponen yang terdaftar di Bursa Efek Indonesia periode 2014-2018.

\section{PENUTUP Simpulan.}

Berdasarkan hasil penelitian yang telah dilakukan, setelah melalui tahap pengumpulan data, pengolahan data, analisis data, dan interpretasi hasil analisis mengenai Pengaruh Rasio Keuangan Terhadap Pertumbuhan Laba pada Perusahaan Sub Sektor Otomotif dan Komponen yang terdaftar di Bursa Efek Indonesia Periode 2014-2018, maka dihasilkan simpulan sebagai berikut :

1. Current Ratio (CR) berpengaruh negatif tidak signifikan terhadap pertumbuhan laba pada perusahaan sub sektor otomotif dan komponen yang terdaftar di Bursa Efek Indonesia periode 2014-2018, dapat diartikan bahwa peningkatan Current Ratio (CR) tidak menjamin adanya peningkatan pertumbuhan laba perusahaan. Hal ini dapat terjadi karena kemampuan perusahaan dalam memenuhi kewajiban jangka pendeknya tidak memberikan jaminan ketersediaan modal kerja guna mendukung aktivitas operasional perusahaan yang bertujuan untuk meningkatkan pertumbuhan laba perusahaan.

2. Total Asset Turnover (TATO) berpengaruh negatif tidak signifikan terhadap pertumbuhan laba pada perusahaan sub sektor otomotif dan komponen yang terdaftar di Bursa Efek Indonesia periode 20142018, dapat diartikan bahwa peningkatan Total Asset Turnover (TATO) tidak menjamin adanya peningkatan pertumbuhan laba perusahaan, hal ini dapat terjadi ketika perusahaan melakukan penurunan harga produknya untuk menghindari depresiasi, dengan demikian nilai Total Asset Turnover (TATO) akan meningkat namun tidak terjadi peningkatan pertumbuhan laba perusahaan.

3. Return On Asset (ROA) berpengaruh positif signifikan terhadap pertumbuhan laba pada perusahaan sub sektor otomotif dan komponen yang terdaftar di Bursa Efek Indonesia periode 2014-2018, dapat diartikan bahwa peningkatan Return On Asset (ROA) akan meningkatkan pertumbuhan laba. Return On Asset (ROA) yang tinggi menunjukkan bahwa perusahaan berusaha meningkatkan pendapatan sehingga pertumbuhan laba perusahaan juga ikut meningkat.

4. Current Ratio (CR), Total Asset Turnover (TATO), dan Return On Asset (ROA) secara bersama-sama (Simultan) berpengaruh signifikan terhadap pertumbuhan laba pada perusahaan sub sektor otomotif dan komponen yang terdaftar di Bursa Efek Indonesia periode 2014-2018, dapat diartikan bahwa peningkatan Current Ratio (CR), Total Asset Turnover (TATO), dan Return On Asset (ROA) secara 
bersama-sama (Simultan) mampu meningkatkan pertumbuhan laba pada perusahaan sub sektor otomotif dan komponen yang terdaftar di Bursa Efek Indonesia periode 2014-2018.

\section{Saran}

Berdasarkan simpulan di atas, maka penulis dapat memberikan saran kepada peneliti selanjutnya untuk menambahkan sampel serta menambahkan variabel selain variabel Current Ratio (CR), Total Asset Turnover (TATO), dan Return On Asset (ROA).

\section{DAFTAR PUSTAKA}

Brigham dan Huston. 2010. Dasar-dasar Manajemen Keuangan. Edisi dua. Diterjemahkan oleh : Ali Akbar. Jakarta : Salemba Empat.

Fahmi, Irham. 2011. Analisis Laporan Keuangan. Lampulo : ALFABETA

Ghozali, Imam. 2013. Aplikasi Analisis Multivariate dengan Program, Edisi 7. Semarang : Badan Penerbit Universitas Diponegoro

Kasmir,2014. Analisis Laporan Keuangan. Jakarta : Rajawali Pers

Mardiyanto, Handoyo. 2009.Intisari Manajemen Keuangan. Jakarta :PT.Grasindo

Nurhadi.2011. Pendekatan dalam Penilaian. Jakarta : Pustaka Sinar Harapan 